\title{
ANNALS OF 'THE CAREERS OF JAMES AND HENRY SHIRLEY.
}

1596, Sep. 13 or 18. James Shirley, descended from the Shirleys of Sussex or Warwickshire, was born near the parish of St. Mary Woolchurch, London.

1608, Oct. 4. He was admitted into Merchant Taylor's school.

1612, Mar. 11. He was 'the eighth boy, or last monitor'.

c. 1612, June 11. He went to St. John's College, Oxford. Dr. W. Laud, then head of that house, objected to his taking boly orders on account of a large mole on his left cheek, and he migrated to Catharine Hall, Cambridge. T. Bancroft the epigrammatist was his contemporary there.

1617-8, Jan. 4. Eccho and Narcissus, the two unfortunate lovers was entered S. R.: a MS. copy of the title page exists; from which it appears that he was then B. A. In the reprint of 1646 the title was changed to Narcissus or the Self-lover.

1619-1622. He took his M. A. degree, assumed holy orders, and obtained a living in or near St. Albans.

1623. He became a master in St. Albans grammar school; adopted the Roman Catholic belief; and resigned his holy orders.

1624. He removed to London and lived in Grays Inn.

1624-5, Feb. 10. Love 'I'ricks with complements was licensed for Queen Henrietta's company acting at the Phonix.

1625-6, Feb. 9. The Maid's Revenge was licensed.

1626, May 31. I assign The Wedding to this date on account of a passage in III. 2 'In witness whereof $I$ have hereunto put my hand and seal... the last day of the first merry month and in the second year of the reign of King Cupid'. Of course the joke consisted in the expectation of the audience that the actor would say 'King Charles'. Compare All Fools at the close and many similar passages in Chapman (one of Shirley's models in Comedy) and Dekker. The date of the play is fixed as between 9. Feb. 1626 when The Maid's Revenge his 'second birth' was licensed and 1629 when The Wedding was printed.

1626, Nov. 4. The Brothers was licensed. This is unquestionably not the play printed under that title in 1652 in a volume with 5 others. Those 6 plays were all acted at Blackfriars by the King's men; after Shirley's return to Ireland. Previously to 1639 be wrote for no com- 
pany but the Queen's. The excellence of this play ought to have made the early date usually assigned to it a matter of suspicion. The 1626 play however is not lost. It has been printed under the title of Dick of Devonshire by Mr. A. H. Bullen and assigned by him to T. Heywood It is expressly stated in the play itself that it contains

'The stories of Two Brothers

Worthy the courtiors' reading'.

And the date of its production is certain. For R. Pike the hero of the play returned 20. April 1626 and the pamphlet about him on which the play is founded is not as stated by Mr. Bullen dateless for it was entered S. R. 18. July 1626 for publication. I may add that the publication of a conjectural query 'can this play be Davenports?' was not authorised by me. 1628, 0ct. 3. The Witty Fair One was licensed.

1629. The Wedding was published.

1629, Nov.3. The Faithful Servant was licensed and on 1629-30, Feb. 26 it was entered S.R. as The Grateful Servant.

1630, Feb. 25. Love Tricks was entered S. R. as The School of Complement.

1631, May 4. The Traitor was licensed.

1681, May 7. The Duke was licensed. I venture to identify this play with The Humorous Courtier. This latter title does not occur in Herbert's list of licenses. The story is of a disguised Duke: and change of title is very frequent in Shirley.

1631, Nor. 14. Love's Cruelty was licensed.

1631-2, Jan. 10. The Changes or Love in a maze was licensed. This is the only play of Shirley's before 1637 not acted by the Queen's men. It was performed by the company of His Majesty's Revels at Salisbury Court thestre. It was entered S. R. 9. Feb. 1631-2.

1632, April 20. Hyde Park was licensed.

1632, Nov. 9. A Dialogue of Riches and Honor by J: S: was entered in $\mathbf{S}$. $R$.

1632, Nov. 16. The Ball by Chapman and Shirley was lieensed. It is elearly an old play by Chapman, altered or rather rewritten by Shirley; and accordingly Herbert, when reprobating the personation of the lords of the Court in it, speaks of it as 'written by Shirley'. Chapman had evidently nothing to do with its production in 1632. My opinion is that the objectionable parts were expunged and replaced by bits taken from Chapman's original play of much earlier date and that these insertions are still clearly perceptible in the duplication of names Stephen, Lionel and Loveall for Lamount, Travers and Rainbow in IV. 3 and V. 1. In no other part of the play can I trace Chapman's hand; but in the account of the lord's travels in $\mathrm{V} . \mathrm{t}$ it is very marked.

1682-3, Christmas. The Queen and other Court ladies acted in a Pastoral play which was supposed to be alluded to in Prynne's Histriomastix published almost simultaneously. Prynne in his index inserted the words 'Women actors. Notorious whores'. And this was the ground of his persecution. The extreme personality of Shirley's ironical dedication of The Bird in a Cage to Prynae inclines me to think that he was the 
author of the Pastoral in question. The Arcadia 'a pastoral' was not licensed by Sir H. Herbert and may therefore have been at first produced elsewhere than at the public theater. Scarcely any plays of Shirley's except those acted in Dublin are missing from Herbert's list. This then was very likely the Pastoral in question. Its peculiar character and careless workmanship look like writing 'by command'; there are a good many' allusious to passages in this pastoral in Heywood's Queen's Masque the scene of which also lies in Arcadia.

1632, Jan. 15. The Witty Fair one was entered S. R.

1632--3, Jan. थ1. The Beanties was licensed. I would identify this play with The Bird in a Cage which title does not appear in Herbert's register. The latter title has a sly reference in it to Prynne's imprisonment 1632-3, during which the play was acted; as appears from the ironical dedication to him in the edition published 10. Mar. 1632-3. S. R. It is not credible that Shirley should have had a play of his performed withont license immediately after his trouble about The Ball: the identity of dates of production of the two plays and the suitability of the title of The Beauties to the extant play leave little doubt that we have here another instance of Shirley's double titles which have hitherto made the chronological arrangement of his plays impracticable.

1633, May 11. Shirley remodelled a play of Fletcher's under the title of The Nightwalker.

1633, July 3. The Young Admiral was licensed. It was praised by Herbert as free from oaths \&c.: it was produced at St..James' before the Court 19. Nov.

1633, Nov. 11. The Gamester was licensed. It was acted at Conrt 16. Feb. 1633--4.

1633-4, Feb.3. The Triumph of Peace was performed at Whitehall by the four Inns of Court. Entered S. R. 24. Jan. and published before the performance 'as it is to be presented'. It passed throngh three editions in as many months.

1634, early. I assign this date to The Constant Maid. It must have been produced before 1133 i because it was actod by Her Majesty's servants at the Phornix (Titlepage of 1661 edition) i.e. before they removed to Salisbury Court. Moreover it contains allusious to The Spanish Tragedy, which seem to point to a revival of that play. At revivals new editions were often called for and in 1633 The Spanish Tragedy was reprinted: it had not been re-issued for ten years. Also in III. 2 the Cousin who personates a King is called 'Excellent Warbeck': he had probably taken that part in Ford's play in 1633. In the 1661 edition a second title Love will find out the way is given. Gifford's date is untenable. In 1661 the anthorship was assigned to T. B. on the ground of sundry alterations in the text of no great importance; in 1667 it was restored to J.S. Mr. P. A. Daniel thinks that T. B. was Thomas Betterton: he also thinks that the 1661 version was the original play: in which $I$ can by no neans agree with him.

1684, Jnne 24. The Example was licensed.

1634, Nov. 3. The 'Traitor was entered S. R. 
1634, Nंov.29. The Opportunity was licensed.

1634-5, Fèb. 6. The Coronation was licensed.

1635, Apr. 29. Chabot the Admiral of France by Chapman and Shirley was licensed. It is evidently an alteration or completion by Shirley of an old play by Chapman with much more of the original remaining than in the case of The Ball. Shirley's hand is not apparent to me until the verse part of III. 1 but Acts IV, V are certainly not Chapman's in their present state.

1635, Oct. 15. The Lady of Pleasure was licensed. It appears from Sir H. Mildmay's diary that it was still on the stage on 8 . Dec.

1635-6, Jan. 18. The Duke's Mistress was licensed. In 1636 the thestres were closed in London on account of the plague and Shirley determined to go to Dublin and produce plays at the theatre opened there in 1635. His connexion with the Phœnix in Drury lane ceases at this point. Before leaving England he write dedications for many plays which had been there performed to be published in his absence; the plays published after his own revision are much more correctly printed than the others and are easily identifiable by the fact that they all have dedications by him prefixed.

1637, April 13. Hyde Park, The Young Admiral, The Lady of Plessure were entered S. R. These all have dedications.

1636-7, winter. Saint Patrick for Ireland was probably the first of Shirley's plays acted in Dublin.

1637, before Oct.2. The dedication to The Royal Master was written. This document of vital importance to the chronology of Shirley's writings has hitherto been entirely misunderstood. It was written in Ireland but before 2. Oct. 163i when the restraint on the English theatres was removed: 'when the English stage shall be recovered from her long silence \&c.' are Shirley's express words. He also tells us the play was 'never yet personated'. It was acted at Dublin Castle before Strafford 1. Jan. 1637-8 (see Epilogue) and still earlier at the Dublin theatre; entered S. R. 13. Mar 1637-8 and licensed for the Queen's men at Salisbury Court 23. April. The only explanation of these dates that seems possible is that Shirley after leaving England soon after May 1636 returned in conformity with his intention stated in this dedication and again went to Ireland before October 1637. This solves all difficulties. Dyce and Gifford give a narrative filled with discrepanices.

1637, Oct. 18. The Example was entered S. R.

1637, Nov. 15. The Gamester was entered S. R.

1637-8, Mar. 18. The Duke's Mistress was entered S. R. with

The Royal Master.

1638. One of the plays performed at Dublin was Middleton's No Wit no Help like a Woman's. The date of this reproduction is expressly mentioned in UI. 1; and in the Prologue Shirley says he had lived two years in Dublin, which fixes the time of his leaving England to 1636, of course after 10. May, when the restraint on plays was issued.

1638, Dec. 24. The Ball and Chabot were entered S. R. and printed without dedications. 
1639, Apr.12. The Maids Revenge was entered S.R. and printed without dedication.

1639, Apr. 25. 'The Nightwalker, The Opportunity, Love's Cruelty and The Coronation were entered S. R. The last named was assigned to Fletcher and though reclaimed by Shirley was retained in the collection of his works in the 1679 folio.

1639, July 20. The Humorous Courtier was entered S. R. and printed without dedication.

1638-9. The Politician was acted at Salisbury Court by the Queen's actors. 'This could not have been the same play as The Politic Father, licensed by Herbert 26. May 1641, for the king's men; for they did not act at this theatre. Dyce's conjecture is absurd and Gifford was as to date in this instance right.

1639, Oct. 30. 'The Gentleman of Venice was licensed, also for Salisbury Court. It was published with the preceding play in 1655.

1689. Saint Alban's was entered S.R. 14. Feb. 1639-40: Look to the Lady on 10. Mar.: and the play called Captain Underwit by Mr. A. H. Bullen must date 1639 winter; the allusions to the Pacification of Berwick (June 1639) and Charles' march into Scotland in the spring fix this date; of course his notion that it might have been produced in 1642 is absurd. The theatres were then shut. The publication of Look to the Lady and The Politician was probably stopped by Shirley on his return to England in 1640 . I think that the six last named plays were acted first in Ireland and afterward at Salisbury Court.

1640, Apr. 28. The Constant Maid and St. Patrick for Ireland were entered S.R. It appears that a dozen plays were printed during Shirley's absence in Ireland undedicated by him and without his supervision. The last of these The Opportunity entered 25. April 1639 was delayed in the press till $1(140$ and early in that year (about March) Shirley on his return found it 'emergent' and prefixed a dedication. Whether he was annoyed, as I think, that the Queen's men should have made his writings public in this way or for some other resson he wrote no more for them; but joined the King's company. The date given by Dyce and Gifford for his final return from Ireland 1638 is incorrect. The Maid's Revenge entered 12. April 1639 would also seem to have been delayed in the press as it has a dedication. The year 1639, be it remembered, did not end till our 25. Mar. 1640.

1640, early. The Triumph of Beauty was personatod by young gentlemen as a private recreation. The antimasque is a burlesque on the City pageants by sea and land on Lord Mayor's day. These had been provided from 1631 to 1639 by Thomas Heywood with two exceptions, viz. in 1636 when the plague was prevalent, and in 1634 when Taylor arranged the show. Heywood was assisted by Gerald Christmas who made monsters of wicker and paper to illustrate the scenes; and after Gerald's death by his two sons. Shirley had in his Honour and Riches 1633 vigorously satirized these pageants and in his Queen's Masque 1634 Heywood had represented Shirley as Corydon the clown. In the present masque Shirley retaliates by introducing Heywood as Bottle. The proof 
of this lies in the fact that almost every line of the Bottle scenes contains allusions to Heywood's works. I have space here only for a few of them. Bottle says 'You all know Paris the prince of Troy'. Crab replies 'We know him now; but it was a mystery for many years'. This alludes to the burlesque account of the rape of Helen in Love's Mistress II. 3. The whale, uwls, ship, fiery dragons, Jason, Hercules, the choice of Paris are every one to be found in Heywood's pageants and especially in $163 \mathrm{~S}$ should be noticed the shepherd with his scrip and bottle whence the names of the two shepherds in Shirley's masque. The Jason story vccurs in the 1639 pageant. An estimate of the literary value of that production of Heywood may be fairly formed from one distich

The Fleece of Aries trumpets to Eternity

The Drapers' honor due to that Fraternity.

Shirley deferred his answer to Heywood's attack till after his return from Ireland and even then did not publish it till 1646. But the date of production of The Triumph of Beauty must have closely followed on Heywood's last pageant containing the Golden Fleece story in 1639. As to the date 1634 herein assigned to his Queen's Masque which Collier magisterially states to have been acted in November 1636 at Court, and 'subsequently' at this Drury Lane thestre, the following facts may serve as a warning to those critics who decry my dates in subservience to his authority. It was entered S. R. 30. Sep. 1635 as The Queen's Masque and (seo Prologue) did not bear that title till after it had been performed at Denmark House on a King's birthday 19. Nov. It must therefore have been so acted in 1634 at latest and an examination of the Revels registers shows that it could not have been earlier. When it was performed on the Stage it was 'fresh and new' and bore the title Lore's Mistress. This was in the early part of 1634 about February. In March Heywood had left the Queen's men and was with Brome writing The late Lancashire Witches for the King's Company. Moreover the King's birthday performance was not the second at Court as Collier says: for a second Prologue expressly informs ns that the second Court presentation was subsequent though in the same week. This digression would have been more in place in a paper on Heywood: but $I$ find that it is dangerous to defer such explanations.

1640, June 1. Rosania was licensed for the King's men at Blackfriars by whom all plays by Shirley where henceforth acted. It had been previously performed at Dublin with the additional title of Love's Victory and was published in 1552-3 with the rest of the Blackfriars plays as The Doubtful Heir. It is a striking example of Shirley's habit of renaming his plays.

1640, Nov.10. The Imposture was licensed.

1641, May 26. The Politic Father was licensed. This could not have been The Politician acted by the Queen's men. It was no doubt the play known as The Brothers which must date in 1641 since the prologue alludes to the King's 'Spanish plot' of that year, viz. to give Spain part of the Irish army. It was published as The Brothers, I suppose, to mislead the licenser, seeing that the play really bearing that title 
and misnamed by its modern editor Dick of Devonshire is quite innocent of political allusions.

1641, Nov.25. The Cardinal was licensed.

1642, April 26. The Sisters was licensed.

1642, Aug. The Court Secret was written but not acted; the theatres being closed on account of the Civil War. Shirley then accompanied the Duke of Newcastle and assisted him in his plays. These ought to be printed with Shirley's. He next retired to London where T. Stanley 'exhibited to him' for the present. Then he again had recourse to teaching, mostly in Whitefriars.

1646. Shirley's Poems were published.

1647. He wrote the address to the Reader for the Beaumont and Fletcher Folio. lished.

1649. The way made plain to the Latin tongue was pub-

1652-3. The plays acted at Blackfriars were published.

1653, Mar. 26. Cupid and Death was performed: it was published the same year.

1655. Phillis of Scyros translated by J. S. was published; Dyce thinks not written by Shirley.

1656. The Rudiments of Grammar was published.

1659. Honoria and Mammon and Ajax and Ulysses were published.

He assisted Ogilby in his Translations.

1666, Oct. 29. James Shirley and Frances his second wife were buried in St. Giles in the fields, having both died in one day overcome with 'disconsolation' at having been driven into the fields from their house near Fleetstreet by the Great Fire.

In the very unsatisfactory reprint of Shirley's plays by Gifford and Dyce no publishers' names are given with the titles of the plays. The subjoined table compiled from the Stationers' Registers will therefore be found useful especially to students who have not access to the British Museum. It will also illustrate the arguments in the foregoing pages.

\begin{tabular}{|c|c|c|c|}
\hline Entry in $\mathbf{8 .} R$. & Publisher. & Play. & $\begin{array}{c}\text { Dedioated by Shirloy } \\
\text { to }\end{array}$ \\
\hline $\begin{array}{r}1629 \\
26 . \text { Feb. } 1630\end{array}$ & J. Grove & $\begin{array}{l}\text { The Wedding } \\
\text { The Grateful Servant }\end{array}$ & $\begin{array}{l}\text { W. Gowre Esq. } \\
\text { Franois Earl of Rut- } \\
\text { land. }\end{array}$ \\
\hline 25. Feb. 1631 & F. Constable & $\begin{array}{l}\text { The School of Compli- } \\
\text { ment }\end{array}$ & W. Tresham Esq. \\
\hline $\begin{array}{l}\text { 9. Feb. 1632 } \\
\text { 15.Jan. } 1633 \\
\text { 19. Mar. } 1633 \\
\text { 24.Jan. } 1634 \\
\text { 3. Nov. 1634 }\end{array}$ & W. Cooke & $\begin{array}{l}\text { The Changes } \\
\text { The Witty Frir One } \\
\text { The Bird in the Cage } \\
\text { The Triumph of Peace } \\
\text { The Traitor }\end{array}$ & $\begin{array}{l}\text { Lady Dorothy Shirley. } \\
\text { Sir E. Bushell. } \\
\text { Master W. Prynne. } \\
\text { The Inns of Court. } \\
\text { William Earl of New- } \\
\text { castle. }\end{array}$ \\
\hline
\end{tabular}




\begin{tabular}{|c|c|c|c|}
\hline Entry in S. R. & Publisher. & P1:5. & $\begin{array}{c}\text { Dedioatod by Shirley } \\
\text { to }\end{array}$ \\
\hline $\begin{array}{l}\text { 13.Apr.1637 } \\
\text { 18. Oct. } 1637 \\
\text { 15. Nov.1637 } \\
\text { 13. Mar. } 1638 \\
\text { 13.Mar. } 1638 \\
\text { 24. Oct. } 1638 \\
\text { 24. Oct. } 1638 \\
\text { 12. Apr. } 1639 \\
\text { 25.Apr. } 1639 \\
\text { 25.Apr.1639 } \\
\text { 25.Apr. } 1639 \\
\text { 25.Apr. } 1639 \\
\text { 29. Nov.1639 } \\
\text { 29. Nov.1639 } \\
\text { 14. Feb. } 1640 \\
\text { 11.Mar. } 1640\end{array}$ & $\begin{array}{l}\text { W. Cooke } \\
\text { W. Cooke } \\
\text { and } \\
\text { A. Crooke } \\
\text { J. Williams } \\
\text { and } \\
\text { F. Egglestone } \\
\text { W. Cooke } \\
\text { J. Williams } \\
\text { and } \\
\text { F. Egglestone } \\
\text { R. Whitaker }\end{array}$ & $\begin{array}{l}\text { The Lady of Pleasure } \\
\text { The Young Admiral } \\
\text { The Example } \\
\text { The Gamester } \\
\text { The Duke's Mistress } \\
\text { The Royal Master } \\
\text { Chabot } \\
\text { The Ball } \\
\text { The Maid's Revenge } \\
\text { 'The Nightwalker } \\
\text { The Opportunity } \\
\text { Love's Cruelty } \\
\text { The Coronation } \\
\text { Arcadia } \\
\text { Love's Cruelty } \\
\text { The trag. of St. Albans } \\
\text { Look to the Lady } \\
\text { St. Patrick for Ireland } \\
\text { The Constant Maid } \\
\text { Rosania } \\
\text { The Imposture } \\
\text { The Brothers } \\
\text { The Cardinal } \\
\text { The Sisters } \\
\text { The Court Secret } \\
\text { The Gent. of Venice } \\
\text { The Politician }\end{array}$ & $\begin{array}{l}\text { Henry Earl of Hol- } \\
\text { land. } \\
\text { Richard Lord Love- } \\
\text { lace. } \\
\text { George Lord Berke- } \\
\text { ley. } \\
\text { George Earl of Kil- } \\
\text { dare. } \\
\text { H. Osborne Esq. } \\
\text { Captain R. Owen. }\end{array}$ \\
\hline
\end{tabular}

Shirley's regular publisher from 1632 onward was W. Cooke who after 1636 usually associated with him A. Crooke. But during Shirley's absence in 1639-40 entries were made by J. Williams and F. Egglestone jointly: also by $R$. Whitaker. That these were of plays surreptitiously obtained is clear: for one of them is of Love's Cruelty which had been previously entered by W. Cooke and another Look to the Lady was in some way stayed. There can be no doubt that Shirley did not authorize any issue by these intruders.

A few supplementary dates of no great importance however, may be gathered from Shirley's Minor Poems. 
1619, Mar. On the death of Queen Anne. Shirley was still B. A. of Catherine Hall.

1625. Upon the death of King James.

1628. Epitaph on the duke of Buckingham.

1630. To Nassinger on his Renegade.

1630. Upon the birth of Prince Charles.

1633. On Ford's Love's Sacrifice.

1634. To the Painter preparing to draw Mrs. Mary Hammond.

1635. An Elegy on Thomas Viscount Savage.

1636. To the Sisters Lady B. and Lady Dia. Curs. at his departure.

1646. To John Hall on Horæ Vacivæ.

1646. To Francis Hawkins on Youth's Behaviour.

1647. Upon the printing of Mr. John Fletcher's Works.

1650. To Major Wright upon his Loving Enemy.

1651. To Thomas Stanley Esq. on his Poems.

1651. To Mr. E. Prestwich upon his Poems.

1651. To Mr. John Ogilby on his Fables of Esop.

1652. To Mr. Richard Brome on A Jovial Crew or The Merry Beggars.

Some further conception of the extent of Shirley's circle of friends may be formed from the Commendations prefixt to The Wedding, The Grateful Servant, The Traitor, The Royal Master, The Cardinal, The Poems and Via ad Latinam Linguam.

\section{ON HENRY SHIRLEY.}

This neglected author is known as having written four plays now lost but entered S. R. 9. Sep. 1653 viz.

The Spanish Duke of Lerma

The Duke of Guise

The Dumb Bawd

Giraldo the constant Lover;

and one other still extant and lately reprinted by Mr. A. H. Bullen. It was entered S. R. 15. Feb. 1637-8 as The Martyred Soldier with the life and death of Purser [and] Clinton. The author was then dead (see the prose address to the Reader) and the play was an old one (see the verse address to the Reader). It was acted by Queen Henrietta's men at the Cockpit but had also been acted at other public theatres. Now this Queen's company was a continuation of the Lady Elizabeth's who before going to the Cockpit had performed at the Hope in 1614 and the Swan in 1612: but never elsewhere than at the Cockpit after 1614. This play then dates c. 1612. Purser and Clinton have nothing to do with it; but their lives and deaths are narrated in Fortune by Land and Sea IV. 1. 2. 3. 4. 5, V. 1 which is attributed in the title page of that play (dating 1655 and therefore of no authority) to Heywood and W. Rowley. I assign these scenes to $\mathrm{H}$. Shirley. They are certainly not Rowley's, whose metre is very easy to recognize and to whom much has been attributed that is not his. 'The date of the execution of Purser alias 
Watton and Clinton has been hitherto unknown: but I have ascertained that it was in 1586. An account of it was entered S. R. 15. Aug. in that year.

I infer from the fact that Henry Shirley preceded James by so many years that he was his father and not his brother as has been generally conjectured. This would agree with my interpretation of Corydon (James) son of Midas (Henry) in Love's Mistress. Great light is thrown on the career of James by this identification and $I$ think it will bear a rigid examination. The Martyred Soldier may be identical with The General acted at Dublin c. 1639 under James Shirley's management.

LoNdON, JULY 1885 . F. G. Fleay. 